\title{
Автохтонні дендросозофіти на територіях природно-заповідного фонду Поліської частини Сумської області
}

Для територій природно-заповідного фонду Сумського Полісся надано інформацію про наявність у їхніх межах рослин, що належать до автохтонних дендросозофітів. Із-поміж рослин, які репрезентують цю групу, виявлено один вид, уключений до «Червоного списку Міжнародного союзу охорони природи і природних ресурсів»; чотири види, занесені до Червоної книги України, та одинадцять таких, що підлягають особливій охороні на території Сумської області. Для досліджуваного регіону проаналізовано систематичну, біоморфологічну та екологічну структури флори цієї групи рослин. Показано, що більшість видів автохтонних дендросозофітів належить до фанерофітів і родин Salicaceae й Betulaceae. У географічній структурі флори найбільшу частку складають рослини, які за зональним типом ареалу входять до бореально-субмередіональних та арктотемператних, а за регіональним типом - циркумполярних та європейських. За ознаками водного режиму більшість автохтонних дендросозофітів репрезентує групи гігрофітів, ксеромезофітів і гігромезофітів.

Ключові слова: автохтонні дендросозофіти, структура флори, природно-заповідний фонд, Сумське Полісся.

Постановка наукової проблеми та їі значення. На сучасному етапі проблема збереження біорізноманіття належить до найактуальніших і визначальних щодо забезпечення існування та розвитку суспільства $[18,20]$. Її розв'язання потребує впровадження комплексу природоохоронних заходів на різних рівнях організації живого: організмовому, популяційному, видовому, екосистемному $[10,21]$. Незважаючи на те, що функціонування матерії на кожному з них має свої особливості, першочерговим заходом щодо збереження біорізноманіття, починаючи від особин до екосистем, $\epsilon$ 3'ясування поширення тих чи інших біологічних об'єктів, у тому числі їх представленості в межах уже відомих природоохоронних територій $[4,13]$. Проведення цих досліджень актуальне для рослин, які належать до групи автохтонних дендросозофітів. Серед них - місцеві види раритетного дендрорізноманіття, які мають офіційний статус, визначений різними рангами охорони (міжнародним, загальнодержавним і регіональним) [6, 8].

Аналіз досліджень цієї проблеми. Окремі види автохтонних дендросозофітів - об’ єкт тривалих наукових досліджень, спрямованих на з’ясування їхніх загальних біологічних, екологічних особливостей та поширення [1-3, 11]. Останнім часом проводять дослідження, спрямовані на більш детальне вивчення властивостей представників цієї групи рослин, у тому числі їхньої декоративності [7], ролі у формуванні фітоценокомпозицій [12], представленості в складі біорізноманіття окремих регіонів $[5,28]$ і територій природно-заповідного фонду [17].

С дані й про наявність деяких видів автохтонних дендросозофітів і в межах природоохоронних територій Сумської області [9, 13]. Однак до сьогодні на теренах області для цієї своєрідної групи видів рослин детальний аналіз як їх поширеності, так і провідних ознак флористичного складу не проводили.

Мета статті - визначити основні особливості поширення та характеристики автохтонних дендросозофітів на територіях природно-заповідного фонду Поліської частини Сумської області.

Завдання дослідження - установити наявність автохтонних дендросозофітів на територіях природно-заповідного фонду Поліської частини Сумської області, для зазначеного регіону й цієї групи рослин з'ясувати систематичну, біоморфологічну, еколого-ценотичну структури флори.

Матеріали й методи. В основу представленої публікації покладено як результати вивчення наявних літературних джерел про території природно-заповідного фонду Поліської частини Сумської області, так і дані власних польових досліджень автора в межах зазначеного регіону. Загалом роботу виконано на основі використання загальноприйнятих геоботанічних i флористичних методів. Перші з них грунтувалися на застосуванні детально-маршрутного вивчення території та супроводжувалися здійсненням геоботанічних описів на облікових площах здебільшого розміром 100 м² $[14,19]$. Для виявлення характерних ознак видового різноманіття флори автохтонних дендросозофітів з опорою на класичні підходи здійснено оцінку систематичної, географічної, біоморфологічної й екологічної структури флори [16, 24, 27].

(C) Скляр М.. 2015 
Виклад основного матеріалу й обгрунтування отриманих результатів дослідження. У межах Поліської частини Сумської області зараз функціонує 30 територій природно-заповідного фонду. Наразі автохтонні дендросозофіти наявні в межах п'яти: одного національного природного парку (Деснянсько-Старогутського) та чотирьох заказників місцевого значення. Із-поміж останніх два $€$ ландшафтними (Діброва, Верхньоесманьський), один - ботанічним (Андріївський) і ще один - загальнозоологічним (Кочубеївський).

Природоохоронна установа Деснянсько-Старогутський національний природний парк має площу 16215,1 га та функціонує з 1999 р. Він створений із метою охорони цілісного лісового масиву, який є південною частиною Брянських лісів, а також природних комплексів долини Десни.

Ландшафтний заказник «Верхньоесманьський» виник у 1994 р. і має площу 2912,5 га. У його межах представлено лісові, болотні та лучні масиви верхів'ї р. Есмань (притоки р. Реть). Заказник «Діброва» (766,7 га) існує з 1994 р. й забезпечує збереження боліт на водорозділі рік Бичиха та Івотка.

Ботанічний заказник Андріївський (37 га) і загальнозоологічний заказник Кочубеӥвський $(149,5$ га) створено в 1994 р. На території першого з них охороняють природні комплекси лісів, другого - боліт.

У межах п'яти зазначених територій природно-заповідного фонду загалом зростає 16 видів автохтонних дендросозофітів. Із них один вид (Juniperus communis L.) уключено до Червоного списку Міжнародного союзу охорони природи і природних ресурсів» [23]. Він же входить і до тих, які підлягають особливій охороні на території Сумської області [15]. Інші чотири види (Betula humilis Schrank, Salix lapponum L., Salix starkeana Willd., Salix myrtilloides L.) занесено до «Червоної книги України [22]. Ще одинадцять видів, як і Juniperus communis, оголошено «регіонально рідкісними» для Сумської області. Це Alnus incana (L.), Andromeda polyfolia L., Arctostaphylos uva-ursi (L.) Spreng., Carpinus betulus L., Cerasus fruticosa (Pall.) Woron., Dianthus pseudosquarrosus (Novak) Klokov, Genista germanica L., Oxycoccus palustris Pers., Salix myrsinifolia Salisb., Salix rosmarinifolia L., Vaccinium uliginosum $\mathrm{L}$.

Найбільша кількість (14) видів автохтонних дендросозофітів зростає на території ДеснянськоСтарогутського національного природного парку. Чотири види - у межах заказника «Верхньоесманьський», а в заказниках «Діброва», Андріївський та Кочубеївський - лише по одному.

Рослини автохтонних дендросозофітів, наявні на територіях природно-заповідного фонду Поліської частини Сумської області, належать до восьми родин. У спектрі родин за кількістю видів перші дві позиції займають Salicaceae і Betulaceae. Вони репрезентують, відповідно, 31,3 та 18,8 \% видів. Хоча родина Salicaceae й представлена найбільшою кількістю видів (п'ять), але всі вони належать до одного роду. Види родини Betulaceae належать до трьох родів, а родин Ericaceae та Vacciniaceae - до двох. Усі ж інші родини мають у своєму складі один рід та один вид (табл. 1).

Табличя 1

Систематична структура флори автохтонних дендросозофітів Сумського Полісся

\begin{tabular}{|c|l|c|c|c|c|}
\hline \multirow{2}{*}{$\begin{array}{c}\text { № } \\
\text { 3/подина }\end{array}$} & \multicolumn{2}{|c|}{ Роди } & \multicolumn{2}{c|}{ Види } \\
\cline { 3 - 5 } & & число & \% & число & \multicolumn{1}{c|}{} \\
\hline 1 & Betulaceae & 3 & 25 & 3 & 18,75 \\
\hline 2 & Ericaceae & 2 & 16,67 & 2 & 12,5 \\
\hline 3 & Vacciniaceae & 2 & 16,67 & 2 & 12,5 \\
\hline 4 & Salicaceae & 1 & 8,33 & 5 & 31,3 \\
\hline 5 & Cariophyllaceae & 1 & 8,33 & 1 & 6,25 \\
\hline 6 & Cupresaceae & 1 & 8,33 & 1 & 6,25 \\
\hline 7 & Fabaceae & 1 & 8,33 & 1 & 6,25 \\
\hline 8 & Rosaceae & 1 & 8,33 & 1 & 6,25 \\
\hline
\end{tabular}

За класифікацією К. Раункієра більшість $(68,8$ \%) видів досліджуваної групи рослин належить до фанерофітів. $€$ серед автохтонних дендросозофітів і хамефіти (Dianthus pseudosquarrosus, Andromeda polifolia, Arctostaphylos uva-ursi, Oxycoccus palustris, Vaccinium uliginosum). Їх частка - 31,2 \%.

Види автохтонних дендросозофітів мають певні відмінності й в особливостях вегетації. Серед них наявні літньо-зелені рослини (68,8 \%), вічнозелені (25,0 \%) та зимово-зелені (6,2 \%). Другу групу репрезентують такі види, як Genista germanica, Cerasus fruticosa, Salix lapponum, Oxycoccus palustris, а останню - Salix myrtilloides. 
За результатами вивчення географічної структури флори встановлено, що серед автохтонних дендросозофітів досліджуваного регіону представлено види, які за зональним типом ареалу належать до арктотемператних, бореальних, арктобореальних, бореально-субмередіональних, бореально-температних, температно-субмередіональних, температних та температно-мередіональних. Найбільшу частку (по 18,75 \%) складають бореально-субмередіональні й арктотемператні види (рис. 1). За регіональним типом ареалу в структурі флори представлено циркумполярні, європейські, європейсько-західносибірські, європейсько-азійські, європейсько-сибірські, європейсько-західноазійські види. Найбільш представлені серед них циркумполярні $(31,25 \%)$ та європейські $(25 \%)$. Європейсько-західносибірські і європейсько-азійські займають третю позицію (12,50 \%), усі ж інші мають лише 6,25 \% від загальної кількості (рис. 2).

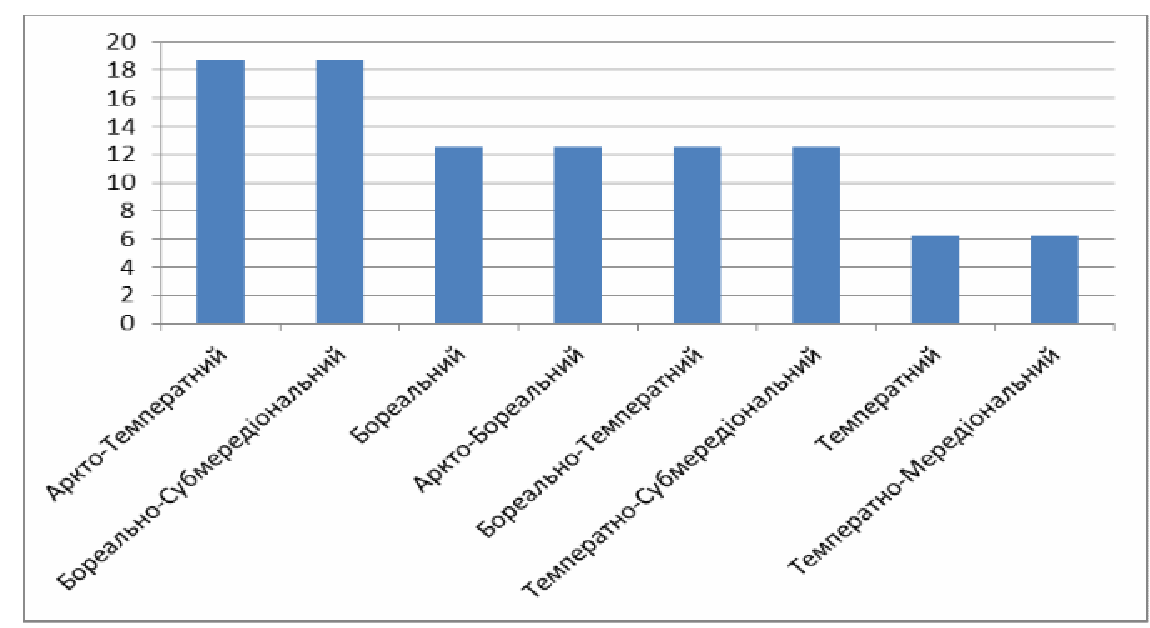

Рис. 1. Географічна структура флори за зональним типом ареалу

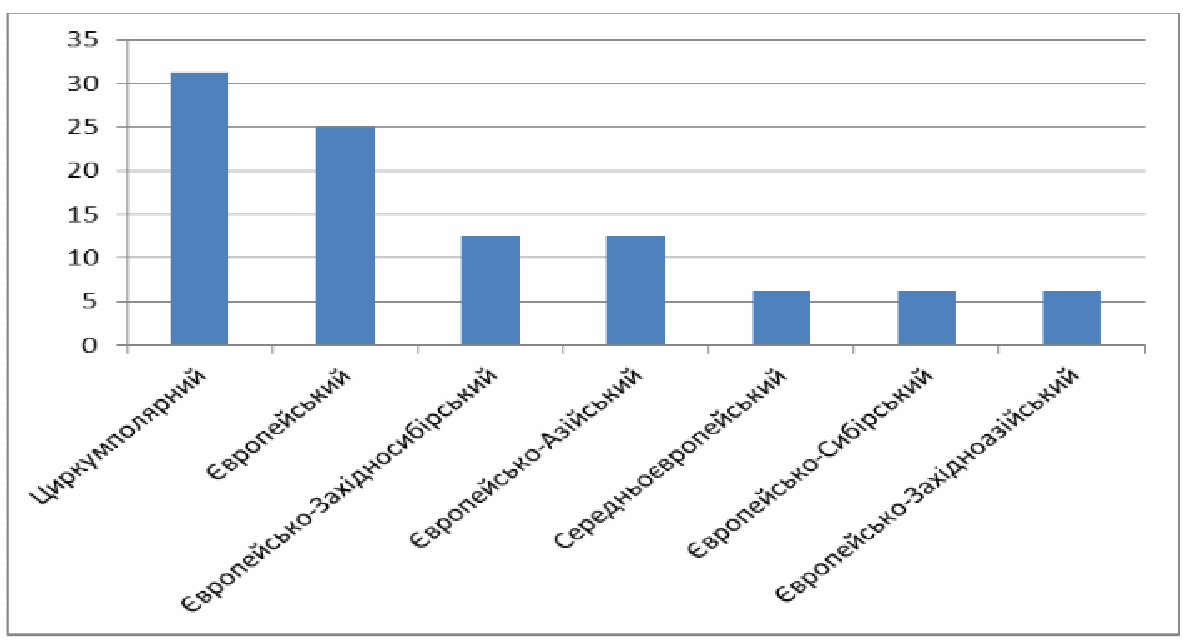

Рис. 2. Географічна структура флори за регіональним типом ареалу

За такою важливою екологічною характеристикою, як особливість водного режиму, автохтонні дендросозофіти територій природно-заповідного фонду Поліської частини Сумської області належать до п’яти груп: гігрофітів (25\%), ксеромезофітів (25\%), гігромезофітів (18,75\%), мезогігрофітів $(18,75 \%)$ і мезофітів $(12,5 \%)$.

Висновки та перспективи подальшого дослідження. У межах Сумського Полісся автохтонні дендросозофіти наявні в межах відносно незначної кількості територій природно-заповідного фонду. Вони переважно зосереджені в Національному Деснянсько-Старогутському природному парку.

Структура флори автохтонних дендросозофітів територій природно-заповідного фонду Поліської частини Сумської області має низку специфічних особливостей. Це, зокрема, проявляється в пере- 
важанні в їі складі частки видів, які належать до родин Salicaceae і Betulaceae, а також у незначній представленості різновидів життєвих форм та типів вегетації. Найрізноманітнішою виявилася географічна структура, що є закономірним наслідком як особливостей розміщення досліджуваного регіону, так і довготривалості й багатоетапності формування його флори.

Перспективою подальших наукових досліджень уважаємо застосування для вивчення автохтонних дендросозофітів популяційного аналізу, методологія якого дасть змогу суттєво поглибити інформацію про стан рослин цієї групи в досліджуваному регіоні, а також розробити ефективні підходи до забезпечення їх охорони.

\section{Джерела та література}

1. Андрієнко Т. Л. Рідкісні виді судинних рослин Українського Полісся / Т. Л. Андрієнко // Укр. ботан. журн. - 2008. - Т. 65, № 5. - С. 666-673.

2. Андрієнко Т. Л. Рідкісні бореальні види на рівнині України / Т. Л. Андрієнко. - К. : Фітосоціоцентр, 2010. - $104 \mathrm{c}$.

3. Андрієнко Т. Л. Центральноєвропейські виді флори Українського Полісся та питання іх охорони / Т. Л. Андрієнко // Матеріали ХІІІ з'їзду Укр. ботан. т-ва. - Львів, 2011. - С. 186.

4. Андрієнко Т. Л. Охорона фіторізноманіття на природно-заповідних територіях України / Т. Л. Андрієнко, В. А. Онищенко // Вісник Запорізького держ. ун-ту. - 2004. - № 1. - С. 19-24.

5. Василик О. В. Заповідні дендросозофіти півдня Правобережного Лісостепу / О. В. Василик // Науковий вісник НЛТУ України. - 2009. - Вип. 9-13. - С. 17-22.

6. Дендросозологічний каталог природно-заповідного фонду Лісостепу України / [під ред. С. Ю. Поповича]. К. : Аграр Медіа Груп, 2011. - 800 c.

7. Дяченко Я. М. Оцінка декоративності заповідних дендросозоекзотів in vivo Лісостепу України / Я. М. Дяченко [Електронний ресурс]. - Режим доступу : http://elibrary.nubip.edu.ua/6793/

8. Заповідна дендросозофлора Лісостепу України / [під ред. С. Ю. Поповича]. - К. : Аграр Медіа Груп, 2010. $-262 \mathrm{c}$.

9. Заповідні скарби Сумщини / [Т. Л. Андрієнко, О. Л. Андрієвська, Р. Я. Арап та ін.] ; під заг. ред. Т. Л. Андрієнко. - Суми : Джерело, 2001. - 208 с.

10.Злобин Ю. А. Популяции редких видов растений: теоретические основы и методика изучения / Ю. А. Злобин, В. Г. Скляр, А. О. Клименко. - Сумы : Университет. кн., 2013. - 439 с.

11. Лукаш О. В. Флора судинних рослин Східного Полісся: історія дослідження, конспект / О. В. Лукаш. К. : Фітосоціоцентр, 2008. - 436 с.

12. Остапенко Г. С. Функціональне зонування Жорнівського парку-пам'ятки садово-паркового мистецтва та його основні фітоценокомпозиції / Г. С. Остапенко [Електронний ресурс]. - Режим доступу : http://elibrary.nubip.edu.ua/17988/

13. Панченко С. М. Лесная растительность Деснянско-Старогутского национального природного парка / С. М. Панченко. - Сумы : Университет. кн., 2013. - 312 с.

14. Полевая геоботаника : [в 4 т]. - М. ; Л. : Наука, 1964. - Т. 3. - 530 с.

15.Про заходи щодо посилення охорони рідкісних та зникаючих видів рослин, тварин і грибів, що підлягають особливій охороні на території Сумської області // Рішення Сумської обласної ради Шостого скликання одинадцятої сесії. - Суми, 2011. - 19 с.

16. Серебряков И. Г. Экологическая морфология растений. Жизненные формы покрытосеменных и хвойных / И. Г. Серебряков. - М. : Высш. шк., 1962. - 378 с.

17. Сиплива Н. О. Фітоценотична структура дендрофлори парків-пам'яток садово-паркового мистецтва Вінниччини / Н. О. Сиплива // Науковий вісник НЛТУ України. - 2012. - Вип. 22.14. - С. 84-89.

18. Ситник К. М. Біотична різноманітність : стан і перспективи вивчення збереження і збагачення / К. М. Ситник // Ботан. і микологія: проблеми і перспективи на 2011-2020 pр. - К., 2011. - С. 28-29.

19. Сукачев В. Н. Методические указания к изучению типов леса / В. Н. Сукачев, С. В. Зонн. - М. : АН ССCР, 1961. - $143 \mathrm{c}$.

20.Шеляг-Сосонко Ю. Р. Ліси України: біорізноманітність та збереження / Ю. Р. Шеляг-Сосонко // Укр. ботан. журн. - 2001. - Т. 58, № 5. - С. 519-529.

21. Шеляг-Сосонко Ю. Р. Стратегія поліфункціональної охорони природних територій / Ю. Р. ШелягСосонко, П. М. Устименко, С. Ю. Попович // Тези доповідей IX з’ізду УБТ. - К. : Наук. думка, 1992. C. $174-175$.

22. Червона книга України. Рослинний світ / [за ред. Я. П. Дідуха]. - К. : Глобалконсалтинг, 2009. - 900 с.

23. Червоний список Міжнародного союзу охорони природи і природних ресурсів [Електронний ресурс]. Режим доступу : http://www.iucn.org/ 
24. Meusel H. Vergleichende Chorologie der Zentraleuropaischen Flora / H. Meusel, E. Jager, E. Weinert. - Jena : Fischer Verl, 1965. - T. 1. - 583 p.

25. Rands M. R. Biodiversity conservation: challenges beyond 2010 / M. R. Rands, W. M. Adams, L. Bennun S. H. [et al.] // Science. - 2010. - Vol. 329, № 10. - P. 1298-1424.

26. Raven P. H. Introduction to special issue on biodiversity / P. H. Raven, J. M. Chase, J. C. Pires // Amer. J. Bot. - 2011. - Vol. 98, № 3. - P. 333-335.

27. Raunkiaer C. Types biologiques pour la geographie botanique. Oversigt over det Kgl. / C. Raunkiaer // Danske Videnskabernes Selsk. Forhandl. - 1905. - № 5. - 236 p.

28. Stepanenko N. P. Comparative analysis of local rare dendroyekzoflor of artificial reserve parks of Foreststeppe of Ukraine / N. P. Stepanenko [Elektronik resourse]. - Mode of access : http://journals.nubip. edu.ua/index.php/Biologiya/article/view/4851

Скляр Марина. Автохтонные дендросозофиты на территориях природно-заповедного фонда Полесской части Сумской области. Для территорий природно-заповедного фонда Сумского Полесья предоставлена информация о наличии в их пределах растений, принадлежащих к автохтонным дендросозофитам. Из числа растений, которые представляют эту группу, здесь выявлен один вид, включенный в «Красный список Международного союза охраны природы и природных ресурсов», четыре вида, занесенные в Красную книгу Украины, и одиннадцать, подлежащих особой охране на территории Сумской области. Проанализирована систематическая, биоморфологическая, экологическая структуры флоры этой группы растений. Показано, что большинство видов автохтонных дендросозофитов принадлежат к семействам Salicaceae и Betulaceae. В географической структуре флоры большую часть занимают растения, которые по зональному типу ареала принадлежат к бореально-субмередиональным и арктотемператным, а по региональному типу - к циркумполярным и европейским. По водному режиму большинство автохтонных дендросозофитов представляет группы гигрофитов, ксеромезофитов и гигромезофитов.

Ключевые слова: автохтонные дендросозофиты, структура флоры, природно-заповедный фонд, Сумское Полесье.

Skliar Maryna. The Autochthonic Dendrosozofits at the Nature reserve Funds of the Sumy Region's Polissya. here is an information provided about presents of the autochthonic dendrosozofits at the nature reserve funds of the Sumy region's Polissya. Among the plants which are represent this group there is one specie from the «Red list of the International Union for Conservation of Nature», four species from the Red Book of Ukraine and eleven species which has to have special protection at the territory of Sumy region. Had been analyzed systematic, biomorphological and ecological flora's structure of this group of plants. Had been showed that the most of the autochthonic dendrosozofits belong to the Phanerophits and to the Salicaceae and Betulaceae families. For the geographical structure we have following results: the biggest number of plants belong to the Boreal-Submeridional and Arctic-Temperate types (zonal structure) and to the Circumpolar and European types (regional structure). For the water regime the most of the autochthonic dendrosozofits are represent groups of hygrophytes, kseromezofites and hihromezofites.

Key words: autochthonous dendrosozofits, structure of the flora, nature reserve fund, Sumy region's Polissya.

Стаття надійшла до редколегії 09.09.2015 p. 